\title{
Platelet Gel in a Non-Regenerating Cryosurgery-Induced Skin Wound in an Old Patient: A Case Report
}

\author{
Orlando Pignalosa ${ }^{a}$ Dario Martusciello ${ }^{b}$ Maria R. De Pascale ${ }^{a}$ \\ Linda Sommese $^{a}$ Giovanni F. Nicoletti $^{\mathrm{b}}$ Angelo Itro $^{\mathrm{b}}$ Francesco Cavalca $^{\mathrm{a}}$ \\ Gianpaolo Tartaro $^{b}$ Claudio Napoli $^{a}$ \\ aUnità Operativa Complessa, Clinical Immunology, Immunohematology, Transfusion Medicine and Transplant \\ Immunology, Regional Reference Laboratory of Transplant Immunology, Department of Internal Medicine and \\ Specialistic Unit, Azienda Ospedaliera Universitaria, Second University of Naples, and ${ }^{\mathrm{b}}$ Multidisciplinary Department \\ of Medical-Surgical and Odontostomatological Specialties, Second University of Naples, Naples, Italy
}

\section{Key Words}

Growth factors · Platelet gel · Skin wound .

Non-regenerating cryosurgery-induced lesions

\begin{abstract}
Objective: To report on the clinical benefits of platelet gel application in a non-regenerating skin wound. Clinical Presentation and Intervention: An 84-year-old man presented with a severe wound with a regular circumference in the frontal region which resulted in a complete loss of epidermis and dermis. The skin lesion, induced by cryosurgery used to remove a basal-cell carcinoma, had previously been treated with a dermal substitute application (Integra $\left.{ }^{\circledR}\right)$. After the failure of the skin graft, the patient was treated using a platelet gel therapeutic protocol which achieved the complete healing of the injured area. Conclusion: This case showed the clinical efficacy of using platelet gel in this elderly patient in whom the dermal substitute graft had been ineffective.
\end{abstract}

(c) 2016 S. Karger AG, Basel

\begin{tabular}{ll}
\hline KARGER & $\begin{array}{l}\text { ( } 2016 \text { S. Karger AG, Basel } \\
1011-7571 / 16 / 0254-0388 \$ 39.50 / 0\end{array}$ \\
$\begin{array}{l}\text { E-Mail karger@karger.com } \\
\text { www.karger.com/mpp }\end{array}$ & $\begin{array}{l}\text { This is an Open Access article licensed under the terms of the } \\
\text { Creative Commons Attribution-NonCommercial 3.0 Un- } \\
\text { ported license (CC BY-NC) (www.karger.com/OA-license), } \\
\text { applicable to the online version of the article only. Distribu- } \\
\text { tion permitted for non-commercial purposes only. }\end{array}$
\end{tabular}

\section{Introduction}

Physiologically, platelets are the first line of defence when a tissue injury occurs [1-3]. The greater part of the platelet secretome is stored in a-granules which contain haemostatic, angiogenic, anti-angiogenic, necrotic factors, growth factors and proteases [4]. For this rationale, platelet derivatives such as platelet-rich plasma and platelet gel (PG) act like a biomolecular cocktail to promote wound healing, angiogenesis, and tissue remodelling, bringing back the skin balance towards synthesis and cell proliferation [5, 6]. Hence, we report a successful case of complete healing with the application of PG in a nonregenerating skin wound after the failure of dermal substitute application.

\section{Case Report}

An 84-year-old male patient presented with a large dermal wound in the frontal region, caused by cryosurgery used to treat a basal-cell carcinoma. At the first visit, at the Division of Oral and Maxillofacial Surgery, Second University of Naples, Italy, the skin

Dr. Linda Sommese, UOC Clinical Immunology, Immunohematology, Transfusion Medicine and Transplant Immunology, Regional Reference Laboratory of Transplant Immunology, Department of Internal Medicine and Specialistic Unit, Azienda Ospedaliera Universitaria, Second University of Naples, Piazza Miraglia 2, IT-80138 Naples (Italy) E-Mail linda.sommese@unina2.it 

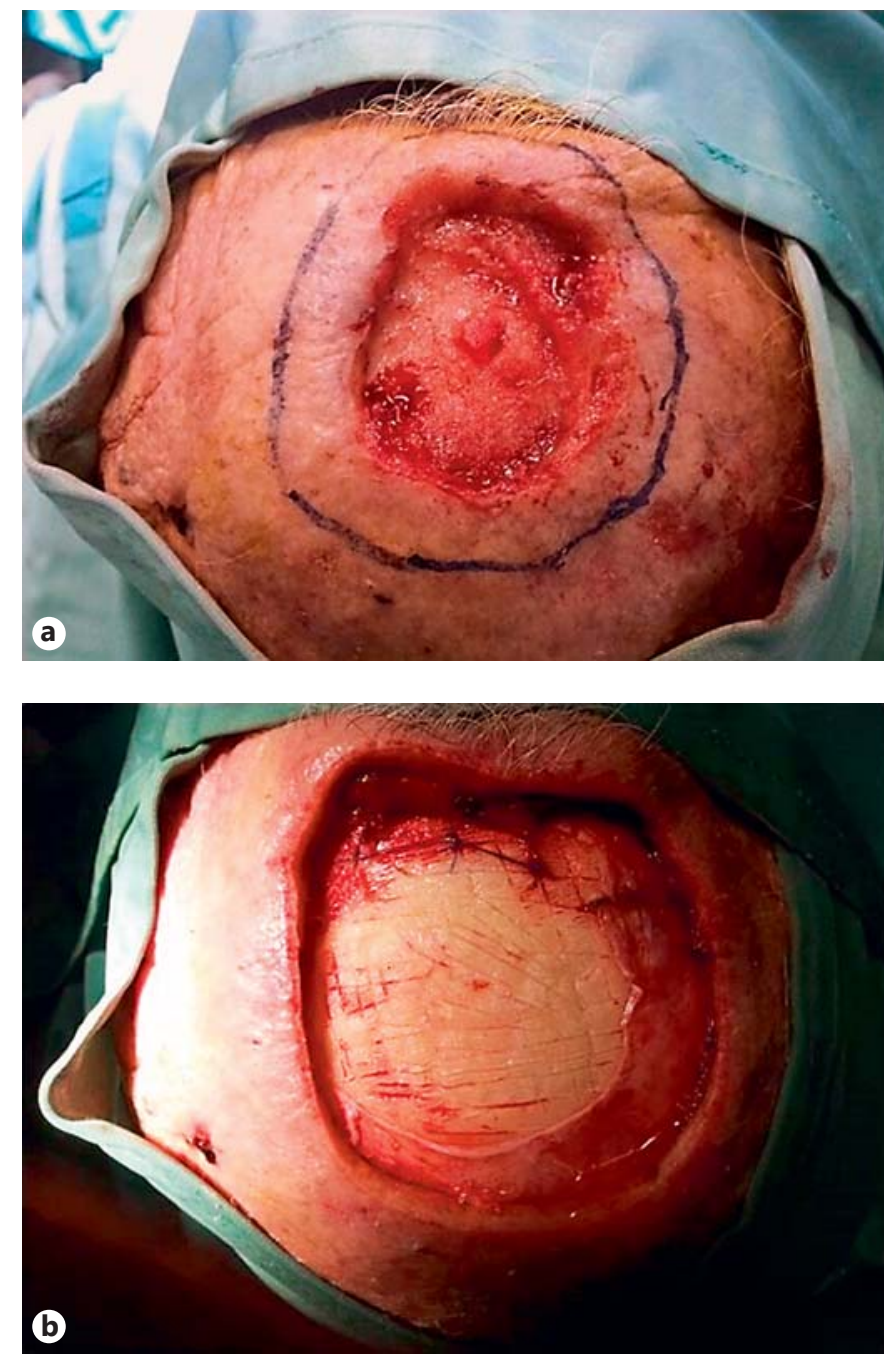

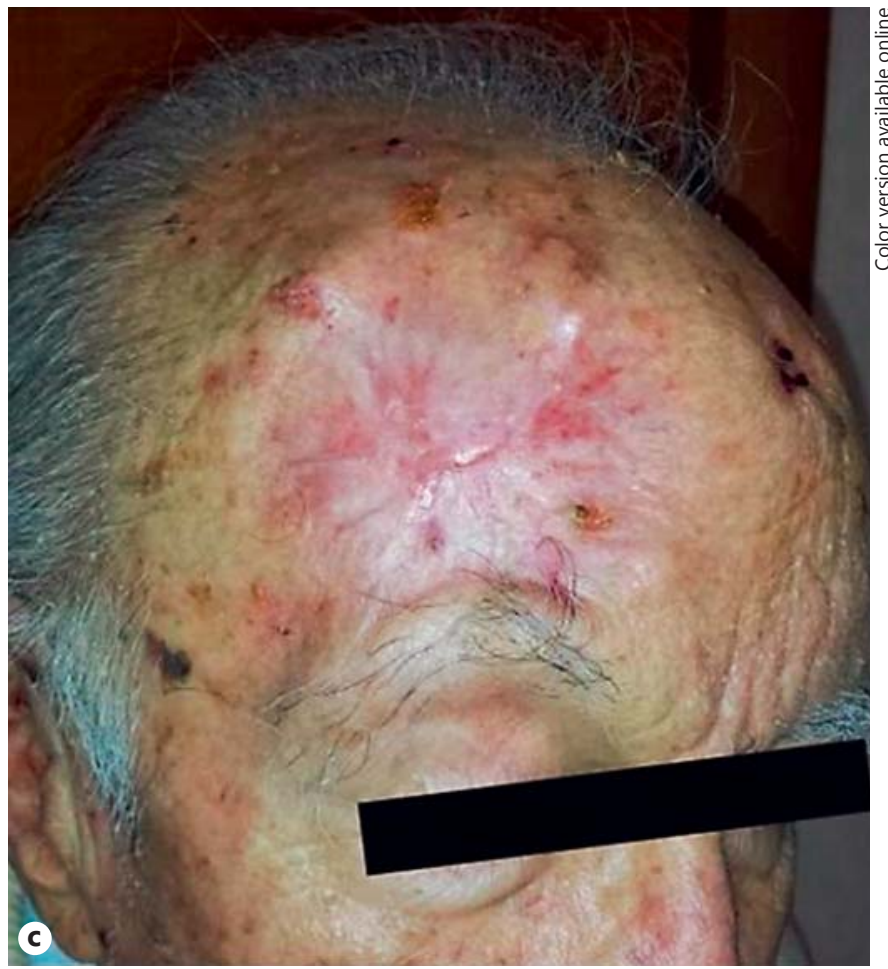

Fig. 1. a Dermal wound after cryotherapy. b Dermal wound after dermal substitute application (Integra ${ }^{\circledR}$ ). c Complete wound healing (day 90) after treatment with PG.

Table 1. Autologous PG treatment and follow-up: wound size $(\mathrm{cm})$

\begin{tabular}{|c|c|c|c|c|c|c|}
\hline & \multicolumn{6}{|c|}{ Days of treatment } \\
\hline Length & 12 & 11 & 7 & 6 & 3 & 0 \\
\hline Maximum depth & 1.2 & 1.2 & 0.5 & 0.3 & 0.2 & 0 \\
\hline
\end{tabular}

lesion had resulted in a complete loss of epidermis and dermis, was egg-shaped and with a regular circumference (the lesion size measured $6 \times 7 \times 1.2 \mathrm{~cm}$, width, length, and depth, respectively; fig. 1a). First, the patient was subjected to the dermal substitute application (Integra ${ }^{\circledR}$; fig. 1b) which required the surgical extension of the injured area. In June 2013, after the failure of the dermal substitute application, the patient was sent to the Department of Immunohematology and Transfusion Medicine Centre of the Second Univer-

Platelet Gel in a Non-Regenerating Skin Wound sity of Naples, Italy, for autologous PG topical applications. The skin lesion measured $10 \times 12 \times 1.2 \mathrm{~cm}$, as reported in table 1 . The therapeutic protocol consisted of 4 applications during a period of 3 months with a biweekly frequency. A written informed consent form was obtained from the patient, and treatment was approved by the Institutional Ethics Committee.

The PG was produced using the whole blood separation system Cytomedix Angel $^{\circledR}$ (Gaithersburg, USA), a technology that en- 
ables the clinicians to obtain platelet-poor plasma, platelet-rich plasma and red blood cells from anticoagulated whole blood. In our case, we got approximately $4-5 \mathrm{ml}$ of platelet-rich plasma and $6 \mathrm{ml}$ of thrombin from $100 \mathrm{ml}$ (ACD-A anticoagulant included) of blood withdrawn for each treatment.

The PG was applied on days $0,14,28$, and 42 as shown in table 1. Earlier changes were observed after the first and second applications of autologous PG (days 0 and 14) such as granulation tissue formation, neovascularization, and wound contraction. At the third application (day 28), the granulation tissue formation and the wound contraction were more evident. After the fourth treatment (day 42), the re-epithelialization process was marked. Clinical controls and wound area measurements (width, length, depth, respectively) were performed until the 60th and 90th days of follow-up (table 1). The complete wound healing was observed at the 3-month of follow up (fig. 1c). Overall, the size of the wound area decreased on average by $1.4 \mathrm{~cm}$ in width, $1.7 \mathrm{~cm}$ in length and $0.7 \mathrm{~mm}$ in depth per week.

\section{Discussion}

This case showed the clinical efficacy of using PG in an elderly patient to completely heal the loss of epidermis, in whom a dermal substitute graft $[7,8]$ had been ineffective. Prior studies had shown the extensive use of plateletderived products for clinical and surgical treatments of wound healing [9]. Clinical efficacy, safeness and costeffectiveness make platelet derivatives a therapeutic option, also for patients whose mechanisms of tissue repair are impaired. The observed regenerative effects of $\mathrm{PG}$ could be achieved by autocrine and paracrine substances including growth factors contained mostly in platelet a-granules. Each growth factor could be implicated in a specific phase of the healing process such as inflammation, collagen synthesis, tissue granulation, and angiogenesis which collectively encourage the impaired tissue repair allowing pain relief [10]. In our patient, the PG was found to be an effective therapeutic tool compared with the dermal substitute application which had failed. To our knowledge, there are no comparative studies on the use of PG versus skin grafts in regenerative medicine.

\section{Conclusion}

PG treatment produced the complete healing within 90 days by enhancing granulation, tissue formation, neovascularization, and wound contraction. No signs of infection or other side effects were observed. The reported clinical evidence showed that PG was an effective tool available in the management of difficult skin lesions.

\section{Disclosure Statement}

There is no conflict of interest.

\section{References}

1 Velnar T, Bailey T, Smrkolj V: The wound healing process: an overview of the cellular and molecular mechanisms. J Int Med Res 2009;37:1528-1542.

2 Barrientos S, Stojadinovic O, Golinko MS, et al: Growth factors and cytokines in wound healing. Wound Repair Regen 2008;16:585601.

3 Picard F, Hersant B, Bosc R, et al: Should we use platelet-rich plasma as an adjunct therapy to treat 'acute wounds', 'burns', and 'laser therapies': a review and a proposal of a quality criteria checklist for further studies. Wound Repair Regen 2015;23:163-170.
4 Nurden AT, Nurden P, Sanchez M, et al: Platelets and wound healing. Front Biosci 2008; 13:3532-3548.

5 Mazzucco L, Medici D, Serra M, et al: The use of autologous platelet gel to treat difficult-toheal wounds: a pilot study. Transfusion 2004; 44:1013-1018.

-6 De Pascale MR, Sommese L, Casamassimi A, et al: Platelet derivatives in regenerative medicine: an update. Transfus Med Rev 2015;1: 52-61.

7 Napoli C, Hayashi T, Cacciatore F, et al: Endothelial progenitor cells as therapeutic agents in the microcirculation: an update. Atherosclerosis 2011;215:9-22.
Heiss C, Keymel S, Niesler U, et al: Impaired progenitor cell activity in age-related endothelial dysfunction. J Am Coll Cardiol 2005; 45:1441-1448.

9 Kazakos K, Lyras DN, Verettas D, et al: The use of autologous PRP gel as an aid in the management of acute trauma wounds. Injury 2009;40:801-805.

10 Miller JD, Rankin TM, Hua NT, et al: Reduction of pain via platelet-rich plasma in splitthickness skin graft donor sites: a series of matched pairs. Diabet Foot Ankle 2015;6: 24972. 